\title{
Perencanaan Desain Fasad Ruang Komersial di Rumah Kos Karangploso, Malang dengan Konsep Arsitektur Industrial
}

\author{
Shofia Khoirunnisa ${ }^{1}$, Aprodita Emma Yetti ${ }^{2}$ \\ ${ }_{1}^{1}$ Program Studi Arsitektur, Fakultas Sains dan Teknologi, Universitas 'Aisyiyah Yogyakarta \\ 2 Program Studi Arsitektur, Fakultas Sains dan Teknologi, Universitas 'Aisyiyah Yogyakarta \\ Email: Shofiakh25@gmail.com
}

\begin{abstract}
Abstrak
Malang merupakan salah satu kabupaten dengan tujuan para pendatang untuk menempuh pendidikan. Hal tersebut menjadi pemicu masyarakat setempat untuk memfasilitasi sarana pendidikan. Rumah Kos Karangploso merupakan rumah kos yang berlokasi di kabupaten Malang. Tepatnya berada di kecamatan Karangploso yang letaknya di sebelah barat laut kota Malang. Berbeda dari kebanyakan rumah kos yang ada di sekitar Rumah Kos. Rumah Kos Karangploso ini memfasilitasi hunian dengan ruang komersial. Pendekatan yang diterapkan dalam desain fasd rumah kos karangploso adalah konsep industrial. Konsep Industrial juga dikenal dengan gaya arsitektur yang menerapkan estetika dan kepraktisan penggunaan barang (usability).
\end{abstract}

Kata Kunci: Malang, Rumah Kos, Ruang Komersil, Fasad, Konsep Industrial.

\begin{abstract}
Malang is one of the districts with the aim of migrants to study. This is a trigger for the local community to facilitate educational facilities. Karangploso boarding house is a boarding house located in Malang district. Precisely located in the district of Karangploso which is located in the northwest of the city of Malang. Different from most boarding houses around the boarding house. This Karangploso boarding house facilitates residential with commercial space. The approach applied in the faade design of the Karangploso boarding house is an industrial concept. The Industrial concept is also known as an architectural style that applies aesthetics and practicality to the use of goods (usability).
\end{abstract}

Keywords: Malang, Boarding House, Commercial Room, Facade, Industrial Concept.

Article history: Received 5 Mei 2020; Revised 15 June 2020; Accepted 25 Okt 2020;

\section{PENDAHULUAN}

Kabupaten Malang merupakan salah satu kabupaten terluas di Provinsi Jawa Timur, dengan luasan wilayah $3.348 \mathrm{~km} 2$ atau sama dengan 334.800 ha. Secara demografis kabupaten Malang memiliki jumlah penduduk sekitar sebesar 2.346.710 jiwa dan merupakan terbesar kedua setelah Kotamadya Surabaya. Kecamatan Karangploso yang merupakan kecamatan di kabupaten Malang ini berlokasi di sebelah barat laut Kota Malang. Malang juga menjadi salah satu kota pendidikan yang ada di Indonesia.

Masyarakat pendatang yang sebagian besar merupakan pelajar dan mahasiswa biasanya membutuhkan tempat untuk tinggal selama beberapa bulan bahkan tahun. Maka tidak jarang masyarakat asli yang memanfaatkan kesempatan ini untuk membangun hingga menyewakan tempat tinggal yang layak bagi para pendatang seperti rumah kos, dan lain-lain. Banyak para pemilik rumah kos yang saling bersaing dari mulai harga sewa, penambahan fungsi ruang hingga estetika. Masing-masing dari rumah kos memiliki keunikan dalam mendesain mulai dari interior hingga eksteriornya. 
Rumah Kos Karangploso merupakan rumah kos yang tidak hanya menyediakan ruang-ruang yang umumnya ada pada rumah kos kebanyakan, tetapi Rumah Kos Karangploso ini juga memiliki ruang yang dimanfaatkan sebagai ruang komersial. Ruang komersial ini terletak di lantai 2 bagian depan Rumah Kos Karangploso. Dengan adanya ruang komersial ini maka dibutuhkan desain fasad Rumah Kos Karangploso yang nyaman dan tidak jauh dari karakter para pengguna ruang komersial ini, tetapi juga tidak terlalu banyak membutuhkan biaya dan tetap ramah lingkungan. Maka dari itu Konsep Industrial yang dapat menjadi solusi dari permasalah tersebut.

Konsep Industrial merupakan desain yang terinspirasi dari bangunan bekas pabrik di Eropa yang dibangun ulang tanpa menghilangkan bentuk aslinya. Konsep industrial juga sangat dikenal dengan gaya konsep yang menerapkan estetika dan kepraktisan dalam pengunaan barang (usability) di suatu tempat. Penerapan konsep industrial sangat mementingkan fisik bangunan tetapi tidak menghilangkan karakter dari asli dari bangunan tersebut. Maka cenderung bangunan yang menerapkan konsep industrial ini tidak diberi finishing dan lebih memilih menggunakan warna-warna monokrom. Penggunaan material dan elemen pada konsep industrial juga cenderung terlihat tegas dan identik tetapi juga mudah didapatkan dan sangat banyak terdapat di pasaran seperti material dan elemen yang berbahan dasar metal, diding bata terekspos, lantai semen atau beton dan terkadang juga menggunakan kayu, dan memiliki warna-warna seperti warna emas dan tembaga.

Berdasarkan hal diatas, maka tujuan dari perancangan ini adalah menerapkan konsep industrial untuk mendesain fasad ruang komersial Rumah Kos Karangploso sebagai pemecahan masalah yang ada. Dibutuhkan material dan elemen pada Rumah Kos Karangploso yang tidak terlalu banyak mengeluarkan banyak biaya, mudah didapatkan dan tetap terlihat estetik tetapi tetap terasa nyaman dan dapat diterima oleh para pengguna yang kebanyakan adalah para pelajar dan mahasiswa.

\section{TINJAUAN PUSTAKA}

Dengan adanya tujuan dari rancangan ini dibutuhkan literatur-literatur sebagai berikut :

\section{Rumah Kos}

Jihan (2017) menjelaskan bahwa, rumah kos atau sering juga disebut dengan kos-kosan merupakan salah satu kebutuhan bagi para mahasiswa yang sedang menempuh ilmu di daerah lain dari luar kampung halaman. Dan rumah kos merupakan kebutuhan utama. Pada umumnya mahasiswa yang memiliki perekonomian tinggi akan tinggal di sebuah apartemen atau guest house atau hotel. Namun bagi mahasiswa yang memiliki kondisi ekonomi menengah kebawah, biasanya akan tinggal di sebuh kamar tinggal yang biasanya di sebut dengan rumah kos, atau sering juga di sebut dengan kos-kosan. 
Wijoyo (2019) menjelaskan bahwa, agar memperoleh rumah rumah kos sesuai dengan yang diinginkan, ada beberapa hal yang mungkin dapat dipertimbangkan oleh mahasiswa sebelum memutuskan rumah rumah kos mana yang akan dipilih. Beberapa hal diantaranya seperti, mahasiswa memilih rumah rumah kos dengan memperhatikan harga sewa rumah rumah kos, kelengkapan fasilitas rumah rumah kos, keunggulan lokasi rumah rumah kos, kenyamanan rumah rumah kos, dan referensi dalam pemilihan rumah rumah kos. Harga sewa rumah kos merupakan salah satu hal yang menjadi pertimbangan mahasiswa dalam memilih rumah rumah kos. Karena jumlah uang masing-masing mahasiswa terbatas sementara kebutuhannya yang banyak membuat pengaturan uang khususnya untuk sewa rumah rumah kos menjadi faktor yang penting. Harga merupakan sejumlah uang yang diserahkan dalam pertukaran untuk mendapatkan suatu barang ataupun jasa yang dinginkan. Dalam penentuan harga sewa rumah rumah kos didapat dari keseimbangan antara permintaan dan penawaran akan rumah rumah kos yang terjadi di dalam pasar jasa rumah rumah kos.

Wijoyo (2019) juga menjelaskan bahwa, kelengkapan fasilitas merupakan salah satu faktor yang mempengaruhi mahasiswa dalam memilih rumah rumah kos. Selain harga sewa, fasilitas juga menjadi faktor penting memilih rumah rumah kos. Fasilitas yang terdapat didalam rumah rumah kos merupakan faktor utama didalam penawaran rumah rumah kos yang ditawarkan pemilik jasa rumah rumah kos. Semakin lengkap fasilitas yang disediakan maka akan semakin tinggi pula harga yang akan ditawarkan, begitupun sebaliknya. Fasilitas-fasilitas yang ditawarkan oleh rumah rumah kos dapat beragam, seperti fasilitas umum (ketersediaan tempat parkir, ruang tamu, dapur umum, tempat memcuci umum dan tempat menjemur) serta fasilitas kamar (kamar mandi didalam kamar, tempat tidur, lemari pakaian, dan meja belajar) bahkan ada juga rumah rumah kos yang sudah melengkapi kamar kosannya dengan semua perlengkapan seperti (AC/kipas angin, televisi, dan gratisnya biaya listrik, sampah, wifi dan laundry) sehingga calon penyewa tinggal membawa pakaian mereka saja, tanpa perlu memikirkan repotnya pindahan barang-barang perlengkapan yang dibutuhkan.

\section{Ruang Komersial}

Menurut Peraturan Pemerintah Republik Indonesia Nomor 36 Tahun 2005 Tentang Peraturan Pelaksanaan Undang-Undang Nomor 28 Tahun 2002 Tentang Bangunan Gedung tidak hanya sebatas digunakan sebagai tempat hunian, tetapi bangunan juga sekarang didirikan untuk menjawab fungsi sebagai fungsi keagamaan, usaha, sosial dan budaya, serta khusus. Rafael (2017) menjelaskan bahwa, bangunan dengan fungsi sebagai usaha didirikan untuk mendukung aktifitas komersial meliputi jual, beli, dan sewa. Bangunan komersial ditujukan untuk keperluan bisnis sehingga faktor lokasi yang strategis memegang peranan penting bagi kesuksesan bangunan tersebut. Contoh-contoh bangunan komersial

Perencanaan Desain Fasad Ruang Komersial di Rumah Kos Karangploso, Malang dengan Konsep Arsitektur Industrial 
di antaranya pasar, supermarket, mall, retail, pertokoan, perkantoran, dan komplek kios.

Bangunan komersial, merupakan bangunan yang direncanakan untuk mendatangkan keuntungan bagi pemilik maupun penggunanya, seperti ruko yang bisa disewakan pemiliknya ataupun sebagai tempat untuk membuka usaha, perhotelan yang berfungsi sebagai tempat menginap bebayar, rumah kos atau apartemen yang disewakan sehingga selalu memberikan penghasilan berkelanjutan. Fungsi komersial meliputi perdagangan seperti ruang kantor sewa, hotel, gudang, pertokoan, supermarket, pusat perbelanjaan dan layanan jasa seperti service, laundry, dll. Untuk lebih menarik sebaiknya bangunan komersial ini merupakan hasil karya arsitektur sehingga mempunyai nilai (niaga) tinggi yang dapat disewakan ataupun diperjual belikan.

\section{Fasad}

Sastra (2013) menjelaskan bahwa, fasad adalah sebagai media untuk menciptakan kesan pertama dan terdepan bagi sebuah karya arsitektur, Fasade merupakan media fisik yang pertama kali dilihat oleh pengamat atau publik dari bangunan. Oleh karena itu dari Fasade tersebut akan banyak menimbulkan berbagai persepsi terhadap Fasade yang diamati. Fasade merupakan elemen estetis dari sebuah bangunan yang sekaligus juga sebagai identitas karya arsitektur yang dijadikan sebagai point of interest dan dapat merepresentasikan karakteristik estetika Fasade serta keunikan gaya arsitektur. Sebagai elemen pertama bangunan yang dapat kita tangkap secara visual, Fasade juga bisa digunakan sebagai patokan / penanda untuk memberi gambaran pada orang lain jika suatu ketika kita ditanya orang tentang letak suatu bangunan tertentu. Misalnya kita dapat menggambarkan bentuk, keunikan atau kondisi Fasade bangunan yang dimaksud atau Fasade bangunan yang berada dekat bangunan yang dituju/dicari.

\section{Arsitektur Industrial}

Jevremovic (2012) memaparkan bahwa arsitektur Industrial merupakan gaya desain dan pemanfaatan konstruksi bangunan yang fungsi utamanya melayani dan mewadahi segala proses kebutuhan industri. Gaya industrial mengacu pada trend estetika dalam desain, dengan penekanan pada penggunaan material mentah atau material dasar seperti semen, bata, besi, dan baja sebagai material utama bangunan. Estetika dari arsitektur industrial dapat merujuk pada pemaparan/ekspos yang disengaja dari elemen-elemen struktural dan mekanikal bangunan. Penggunaan bahan dan metode konstruksi yang ekonomis, yang seringkali tidak disembunyikan atau disamarkan oleh berbagai finishing. Saat ini, pendekatan ini digunakan secara estetis di semua jenis bangunan, tidak hanya pabrik dan gudang, tetapi juga semakin banyak digunakan untuk apartemen loteng, ruang komersial, dan bahkan beberapa rumah modern. 
Journal of Architecture Student, Vol 1, No 2 (2020): November (109-119)

Dalam sejarahnya, gaya industrial sudah ada dan dikenal lama di dunia arsitektur. Arsitektur Industrial muncul sebagai perlawanan dari era factory building/bangunan pabrik yang berakhir pada pergantian abad kedua puluh. Pada awal 1900-an, bangunan pabrik biasanya terbuat dari kayu dan batu dengan jendela kecil serta kolom yang membatasi cahaya matahari dan ventilasi. Ruang kerja yang diciptakan oleh struktur ini seringkali gelap, berpasir, sempit, dan berbahaya. Kehidupan pabrik di era ini bukanlah lingkungan kerja yang memadai dan menimbulkan masalah kesehatan yang sangat tinggi. Para arsitek seperti Albert Kahn, Mies Van der Rohe, Le Corbusier, datang dan membangun pabrik-pabrik industri yang lebih efisien sebagai solusinya.

\section{PROSES RANCANG DAN EKSPLORASI}

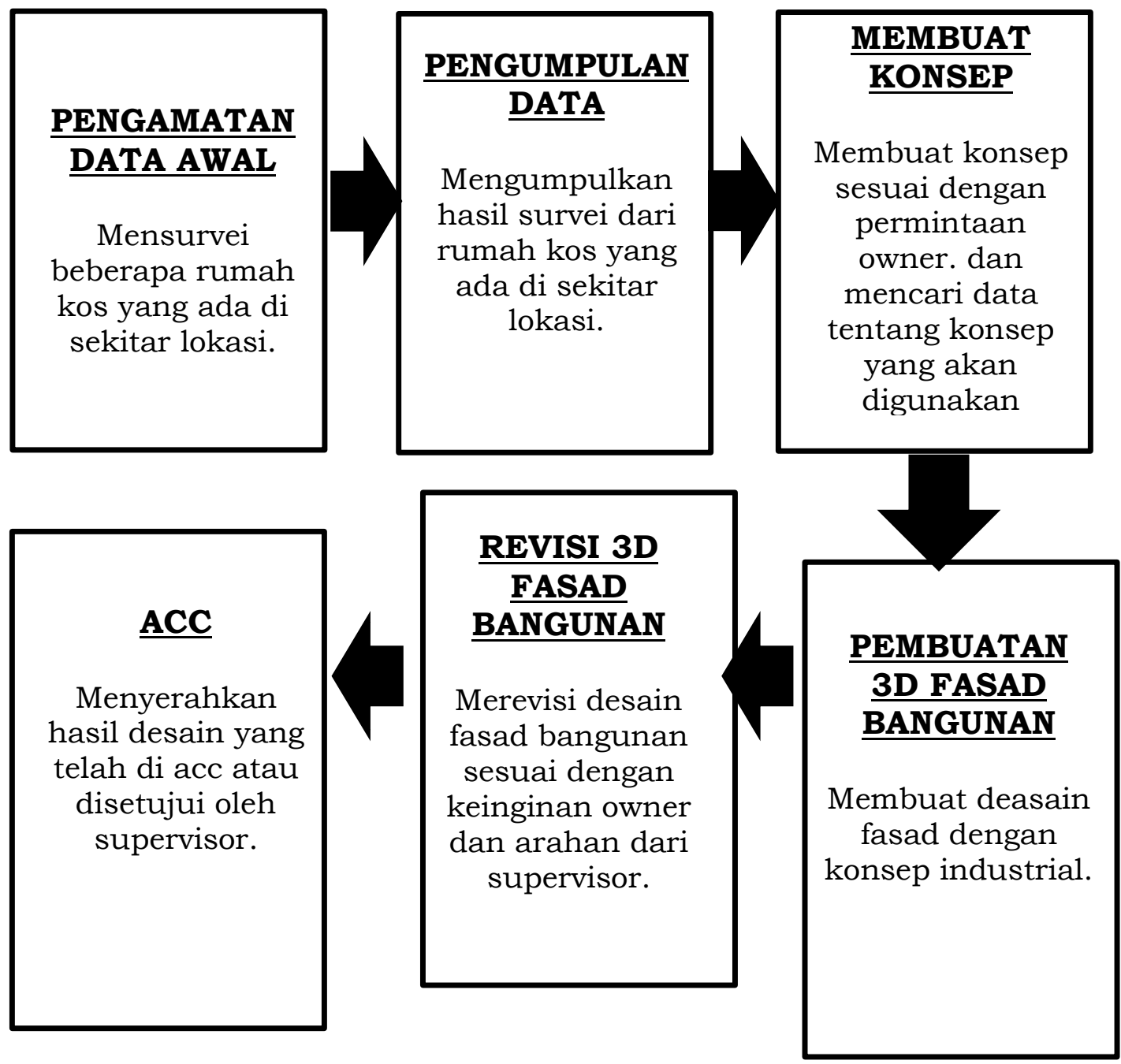

Gambar 1. skema proses perancangan

Sumber: olahan pengarang, 2019 
Pada proses perancangan dan eksplorasi perancangan fasad Rumah Kos Karangploso ini memerlukan pengamatan area sekitar lokasi. Banyak didapatkan bahwa sekitar lokasi dari Rumah Kos Karangploso adalah area perumahan dan rumah kos. Berikut adalah hasil pengamatan dari rumah kos yang ada di sekira lokasi :

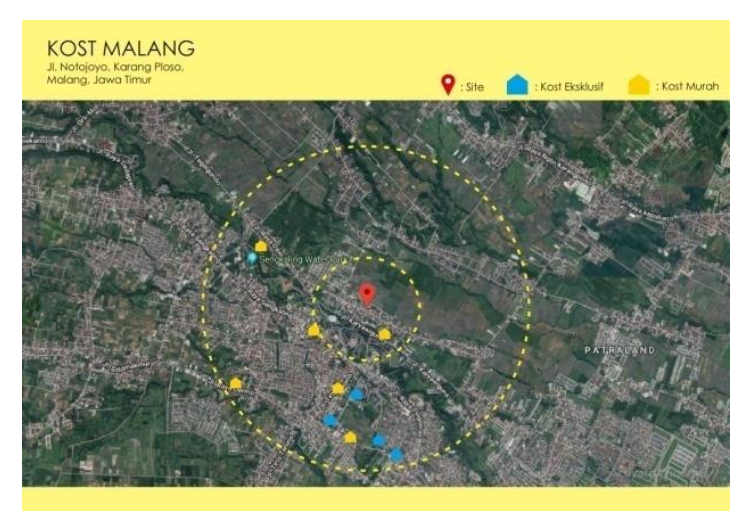

Gambar 2. gambar hasil survei Sumber: google maps, 2019

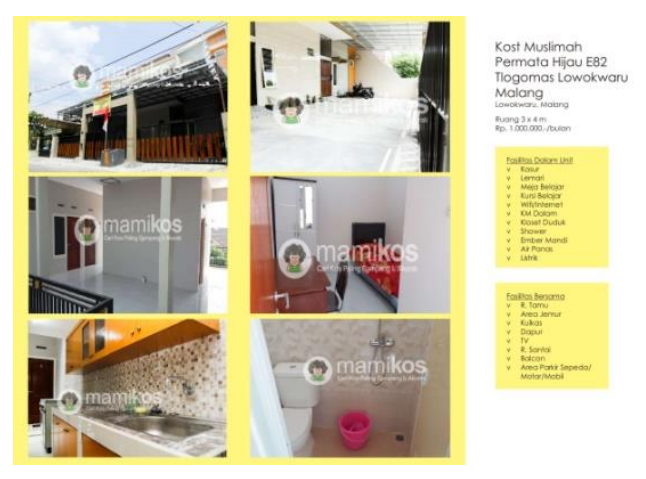

Gambar 3. gambar hasil survei Sumber: diunduh pada mamikos, 2019

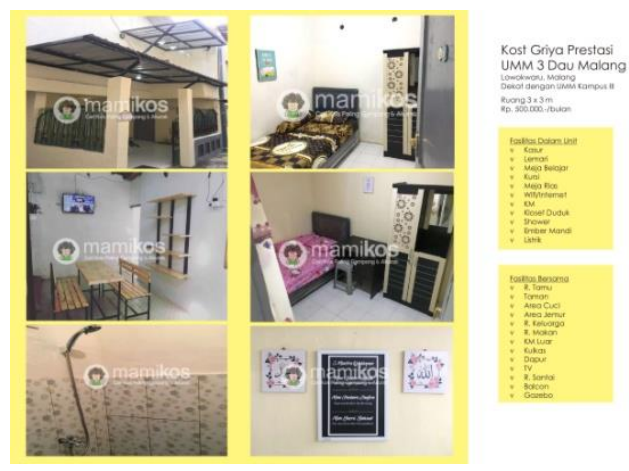

Gambar 4. gambar hasil survei Sumber: diunduh pada mamikos, 2019 


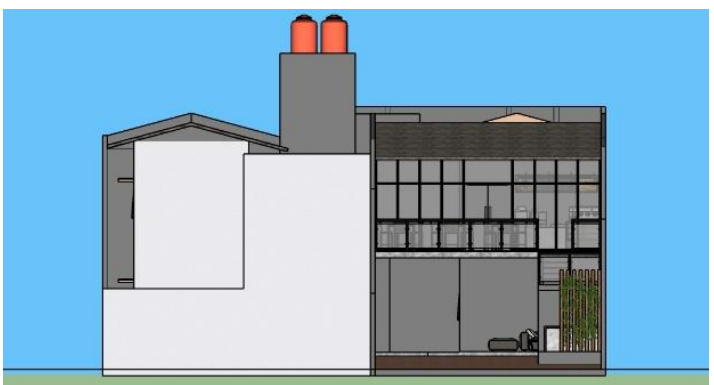

Gambar 5. gambar fasad sebelum didesain Sumber : olahan penulis, 2019

Pengamatan dengan mensurvei rumah kos yang berada disekitar lokasi Rumah Kos Karangploso ini ditemukan bahwa kebanyakan rumah kos disana belum ada yang menambahkan ruang komersial dan tidak ada yang menerapkan konsep industrial sebagai desain fasad rumah kos. Dengan menerapkan konsep industrial pada ruang komersial Rumah Kos Karangploso ini sangatlah nyaman dan sesuai dengan karakter dari para pengguna yang kebanyakan merupakan pelajar dan mahasiswa. Dengan pendekatan konsep industrial ini juga sangat efisien dan hemat biaya dalam penggunaan material dan elemen yang akan digunakan. Material yang akan digunakan dalam merancang konsep industrial ini hanya menggunakan tembok bata ekspos, disini batu bata ekspos tidak lagi menggunakan finishing seperti plester ataupun yang lain. Pada material lantai disini akan menggunakan bahan yang mudah ditemukan yaitu kayu, material sebagai ventilasi udara ataupun railing juga hanya membutuhkan kaca dan besi sebagai pengikatnya. Material yang digunakan sebagai furniture seperti meja dan kursinya pun sangat mudah di cari, hanya memerlukan kayu dan besi saja.

\section{HASIL RANCANGAN}

\section{TAHAP PENGERJAAN FASAD ALTERNATIF 1}

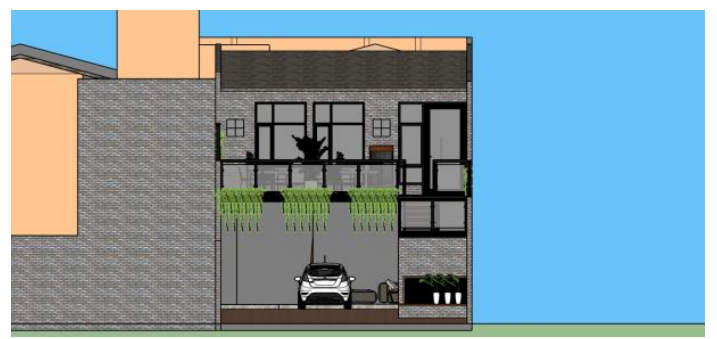

Gambar 6. gambar fasad alternatif 1

Sumber : olahan penulis, 2019 


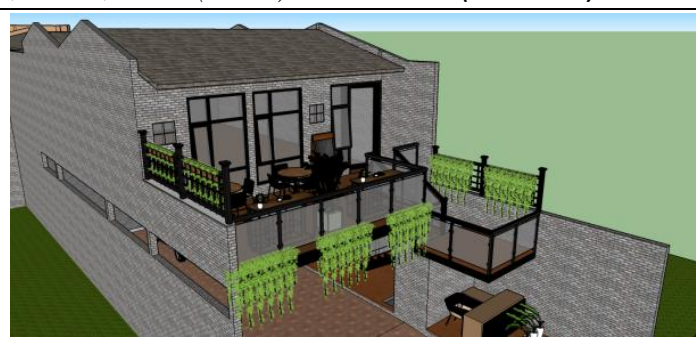

Gambar 7. gambar perspektif alternatif 1

Sumber : olahan penulis, 2019

Pengerjaan fasad dengan konsep industrial alternatif pertama ini hanya berupa menambahkan material-material yang sesuai dengan konsep industrial saja. Seperti penggunaan batu bata ekspos, kayu dan sebagainya. Pada pengerjaan ini penulis menambahkan finishing cat putih pada batu bata. Penulis menggunakan bata ekspos pada keseluruhan ruang komersial, mulai dari bagian depan, interior hingga bagian samping bangunan, dan juga penerapan pada area parkir.

\section{TAHAP PENGERJAAN FASAD ALTERNATIF 2}

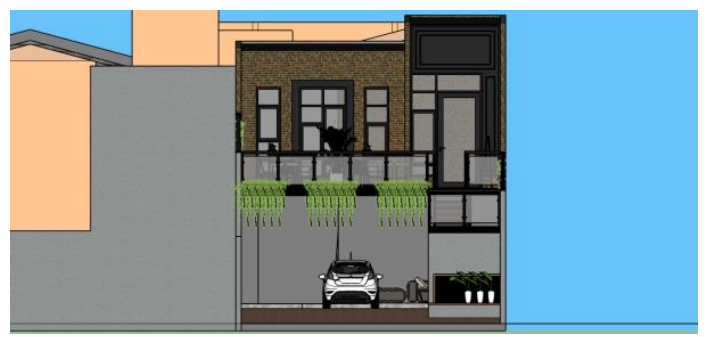

Gambar 8. gambar fasad alternatif 2 Sumber: olahan penulis, 2019

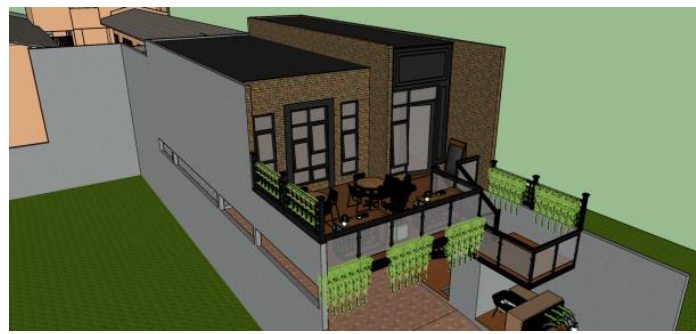

Gambar 9. gambar perspektif alternatif 2 Sumber: olahan penulis, 2019

Pada tahap pengerjaan alternatif 2 ini adalah merubah penggunaan bata ekspos yang awalnya menggunakan bata dengan menggunakan finishing cat warna putih di rubah menjadi bata merah tanpa finishing. Pada tahap ini penggunaan bata ekspos hanya di terapkan pada bagian depan ruang komersial saja. Pada tahap ini juga mulai memaju mundurkan bagian depan 
Journal of Architecture Student, Vol 1, No 2 (2020): November (109-119)

ruang komersial. Disini ada penambahan point of interest yang juga berlaku sebagai pintu masuk ruang dalam. Desain pada jendela pada tahap ini juga sedikit dirubah, yang awal mulanya hanya memiliki 2 jendela besar, disini dirubah menjadi 3 jendela yang terpisah yang memiliki ruas-ruas.

\section{TAHAP PENGERJAAN FASAD TERAKHIR}

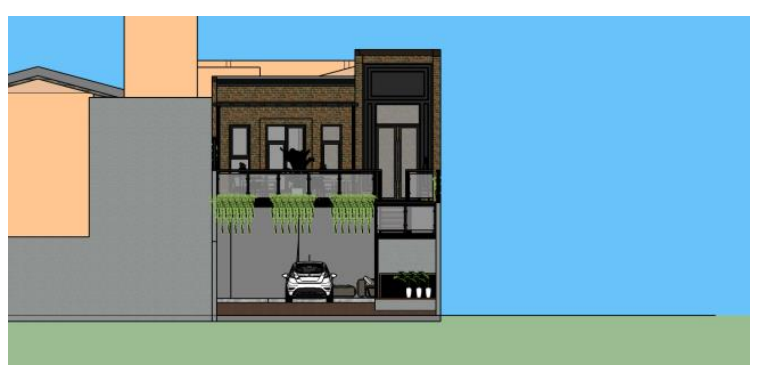

Gambar 10. gambar perspektif terakhir Sumber : olahan penulis, 2019

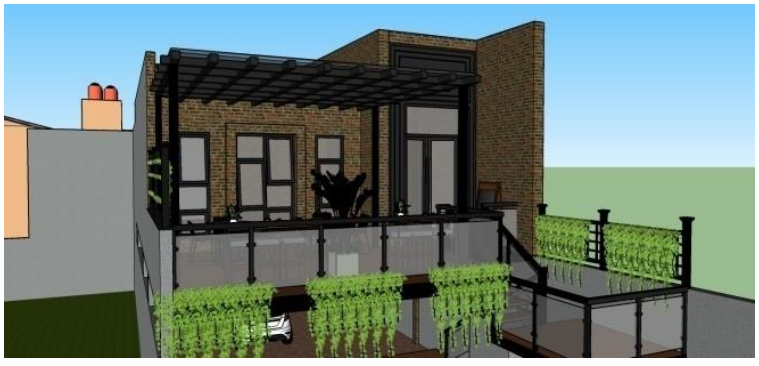

Gambar 11. gambar perspektif terakhir Sumber : olahan penulis, 2019

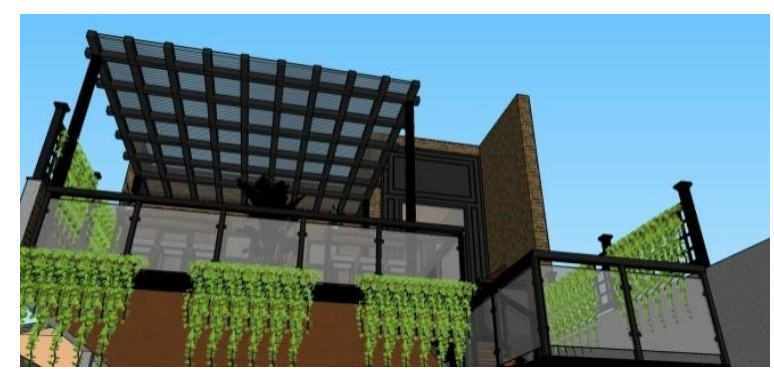

Gambar 12. gambar perspektif 2 terakhir Sumber : olahan penulis, 2019 


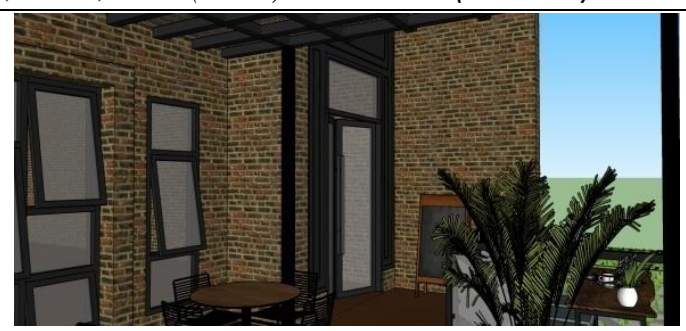

Gambar 13. gambar detail fasad terakhir Sumber : olahan penulis, 2019

Fasad terakhir disini menambahakan atapan pada teras dan mengubah bagian point of interestnya menjadi lebih baik. Pada perubahan fasad terakhir ini lebih tertata dan lebih rapi. Penerapan pada tahap ini menggunakan material sesuai dengan konsep industrial yaitu batu bata ekspos, disini menggunakan batu bata merah, pada bagian atap menggunakan baja berwarna hitam dan penutupnya menggunakan jaring-jaring untuk meminimalisasikan jatuhnya air hujan, railing disini dominan menggunakan kaca agar terasa tidak ada sekat dan lebih luas. Furniture yang digunakan juga lebih mudah ditemukan, seperti meja kayu.

\section{SIMPULAN}

Pada pengerjaan fasad sebuah Rumah Kos yang di fungsikan sebagai ruang komersil ini dibutuhkan konsep yang dapat membuat para pengguna merasa nyaman dan sesuai dengan selera tetapi tidak mengeluarkan banyak biaya dan material yang akan digunakanpun harus mudah ditemukan. Maka dengan menerapkan konsep industrial pada fasad ruang komersial Rumah Kos Karangploso ini kita dapat membuat rumah kos lebih nyaman danmenarik tetapi tetap dapat mengikuti selera pasar terutama palajar dan mahasiswa. Pada desain yang diterapkan ini tidak dibutuhkan banyak material dan juga materialnya sangat mudah ditemukan, seperti kaca, besi, baja dll. Dan fasad rumah kos ini juga tidak membutuhkan finishing untuk hasil akhir, tanpa adanya finishing membuat fasad rumah kos ini akan lebih terlihat estetik dan indah.

\section{DAFTAR RUJUKAN}

Amini, Aisyah Risti. 2019. Penerapan Prinsip Arsitektur Industrial dalam Produktifitas Ruang pada Solo Creative design center.Jurnal SeTHong, Vol. 2, No.2.

Jihan. 2017. Problematika Perjanjian Sewa-Menyewa Rumah Kos Dengan Perjanjian Lisan (Studi Kasus Di Rumah Kos Wisma Pratiwi). Skripsi DIterbitkan. Surakarta: Universitas Muhammadiyah Surakarta.

Pattileamonia, Ria A V. 2016. Pusat Kebudayaan Maluku di Yogyakarta. Tugas Akhir Diterbitkan. Yogyakarta: Universitas Atma Jaya Yogyakarta. 
Rafael, Rio Y. 2017. Analisis Pemeliharaan Green Building. Tugas Akhir Diterbitkan. Yogyakarta: Universitas Atma Jaya Yogyakarta.

Wijoyo, Setyo. 2019. Faktor-Faktor Pertimbangan Mahasiswa Universitas Lampung dalam Pemilihan Rumah Indekos di Kelurahan Kampung Baru dan Gedung Meneng Bandar Lampung. Skripsi Diterbitkan. Bandar Lampung: Universitas Lampung. 